
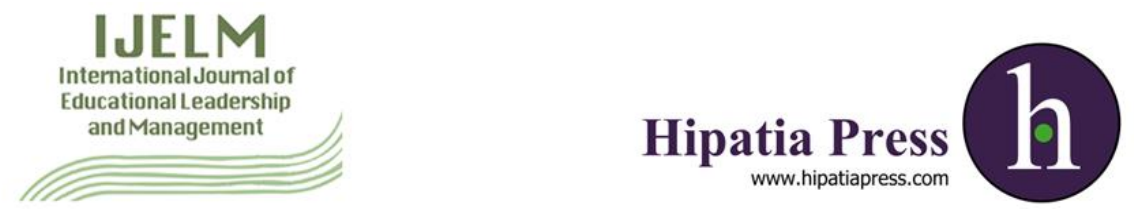

Instructions for authors, subscriptions and further details:

http://ijelm.hipatiapress.com

\title{
Utilizing Humor to Enhance Leadership Styles in Higher Education Administration
}

Beverlyn E. Grace-Odeleye \& Jessica Santiago ${ }^{1}$

1) University of Pennsylvania. United States

Date of publication: July $16^{\text {th }}, 2019$

Edition period: July 2018 - July 2019

To cite this article: Grace-Odeleye, B. E. \& Santiago, J. (2019). Utilizing Humor to Enhance Leadership Styles in Higher Education Administration. International Journal of Educational Leadership and Management, 7(2), 171202. DOI:10.17583/ijelm.2019.3912

To link this article: http://dx.doi.org/10.17583/ijelm.2019.3912

\section{PLEASE SCROLL DOWN FOR ARTICLE}

The terms and conditions of use are related to the Open Journal System and to Creative Commons Attribution License (CCAL). 


\section{Utilizing Humor to Enhance Leadership Styles in Higher Education Administration}

Beverlyn E. Grace-Odeleye

East Stroudsburg University

\author{
Jessica Santiago \\ East Stroudsburg University
}

\section{Abstract}

This review examined the literature addressing humor as a potential trait that may enhance leadership styles in higher educational administration. It provides an overview of current humor research from several disciplines of major contemporary leadership theories and styles in higher educational administration and develop and propose a theoretical link between humor as functional management communication for enhancement to other leadership characteristics. The framework developed in this analysis offer a suitable range of humor and its implications for leadership and leadership development in university environments for more effective leadership competencies to manage the multi-dimensional intricacies and practicalities. Additionally, the review provides strategic insights, and practical ways of incorporation of humor into leadership styles in higher education administration along with suggestions for further empirical exploration on relationships of humor and leadership effectiveness.

Keywords: Higher educational administration leadership, humor, competencies, transformation, leadership theories and practice

2019 HipatiaPress

ISSN: 2014-9018

DOI: $10.17583 /$ ijelm.2019.3912 


\section{Uso del humor para Mejorar los Estilos de Liderazgo en la Educación Superior}

Beverlyn E. Grace-Odeleye East Stroudsburg University
Jessica Santiago

East Stroudsburg University

\section{Resumen}

Esta revisión examina la literatura que aborda el humor como un rasgo potencial que puede mejorar los estilos de liderazgo en la dirección escolar de la Educación Secundaria. Proporciona una visión general de la investigación actual del humor en varias disciplinas y en las principales teorías y estilos de liderazgo contemporáneo en la dirección de la educación superior. Desarrolla y propone un vínculo teórico entre el humor como comunicación de gestión funcional para mejorar otras características del liderazgo. El desarrollo del marco teorico ofrece un análisis del humor y sus implicaciones para el liderazgo y el desarrollo del liderazgo en entornos universitarios para que las competencias de liderazgo sean más efectivas para gestionar las complejidades y aspectos prácticos multidimensionales. Además, la revisión proporciona perspectivas estratégicas y formas prácticas para incorporar el humor en los estilos de liderazgo en la administración de la educación superior, junto con sugerencias para una exploración empírica adicional sobre las relaciones del humor y la eficacia del liderazgo.

Palabras clave: Dirección escolar en educación superior, humor, competencias, transformación, teorías y prácticas de liderazgo. 


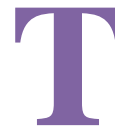
here has been a growing interest in the role of leadership within higher education institutions administrations and leadership in recent including globalization of higher education, diversity of the students population and the "customer" services they require, the assortment of the core teaching and research activities of the institution, and the comparable change in management functions of colleges observed since the 1980s (Amey, 2006; Astin \& Astin, 2000; Drew, Ehrich \& Hansford, 2008).

A number of academic disciplines mostly from the business domains enlightens higher educational leadership and services professional theories and practice. These theories of management, human resources, marketing, educational research, and leadership studies underlies the effective administration and leadership of the wide variety of higher educational leadership styles that drives innovative students' services. Current frameworks of leadership in the Higher Education sector however do not encompass all of the behaviors expressed in established leadership literature given the major differences between the business or non-academic and the academic world. Leadership roles in academic institutions have a number of differences; whilst traditional senior executive roles (e.g. Vice-Chancellor, Chief Executive, President, Vice-President, pro-Vice Chancellor) resonate with roles encountered in other sectors, academic leadership roles (such as Deans, Heads of School or Department Chairperson) are unusual and commonly have complications that are transitory, rotating or secondment nature of leadership role-holders. Also, traditionally in some situations, leadership roles are given on an almost honorary basis and conferred by academic productivity, other non-traditional leadership basis or to the most senior or established professor (Davies, Hides, \& Casey, 2001).

Administrative and leadership faculty positions usually combine the role of teacher, scholar, and researcher (Astin \& Astin, 2000) all of which have leadership responsibility in some form or other, either explicitly or implicitly specified within the role. In addition to the nuanced challenges of these traditional structural legacy, the demands and expansion of student numbers, provision of "holistic student experience" for integrated learning, lifestyle, 
social and developmental provision to students demands, a highly woven arrangement of work between academic and service departments, increased marketization and student choice (Davies, Hides, \& Casey, 2001) wield pressures on higher educational institutions leadership on delivering with operational efficiencies. Higher Education leaders need a combination of leadership, academic and management competencies to address challenges faced using new models of leadership styles focused on novel leadership concepts, models, and practices specific to higher educational administration (Alexander, 2000).

This new model of leadership characteristics and behaviors is needed to "lubricate" the social complex machinery of higher educational institutions, provide the flexibility needed to work through many unforeseen contingencies, and help employees in the organization cope with the awesome tasks of promotion of interdependence of all units within and outside the institution - for example, interaction with state and federal government legislatures, research and grant funding agencies, and parents and students' concerns.

Effective leadership is required at all levels of institution's administration to navigate, survive and thrive these changes in college and university administration and delivery services, differentiate the conceptual, strategic, and operational dimensions to leadership education. This need for a new paradigm of leadership is higher education administration is supported by studies that show strong correlations between leadership management styles and performance in higher education institutions and in open systems (Kieu, 2010; Black, 2015), the practical use of humor as contributory qualities for effective leaders remain to be fully elucidated empirically (Holmes \& Marra, 2006).

This gap in knowledge within the diversity of student services and outcomes does not allow for the informed promotion and/or adoption of specific leadership models and best practices. Therefore, policy makers lack the evidence that serve as the basis for the support of specific approaches to leadership training or follows a practical manual for incorporation of best 
practices into the development, implementation and assessment of student affairs leadership training programs (Gigliotti, 2017; Gigliotti \& Ruben, 2017; Gmelch \& Buller, 2015).

Communication at the strategic, teams and external levels is at the core of mandatory skills for leadership (Ruben \& Gigliotti, 2017; Miller, 2019). The subject of humor as a powerful tool in effective leadership communication has been defined and used in a range of literatures like applied psychology (Cooper, 2005; Warren \& McGraw, 2016); relationship to team or group effectiveness, and work groups integration and socialization (Romero \& Pescosolido, 2008; Mak, Liu \& Deneen, 2012); communications and teaching tool (Riesh, 2014; Chiew, Mathies \& Patterson, 2019); leadership style and performance (Mao, Chiang, Zhang \& Gao, 2017). Although studies have examined humor in leadership, the literature is most often conceptual, and does not empirically examine the value of humor in leadership for service organizations (Slåtten, Svensson, \& Sværi, 2011).

A purpose of this review is to provide links between models of educational management leadership styles and the use of humor - as forms of communication, by more effective leadership for enhanced organizational performance despite the parallel and sometimes interweaving evolution of leadership ideologies. The essay focus on research on the effects of the two major leadership contemporary leadership theories - distributed and transformational leadership, on student services. It addresses the link between leadership important traits and competency of leaders and attempt to evaluate the contribution of the two theories to service improvement through an examination of their limitations and weaknesses. The paper begins with an overview of major students' services and the major tenets under-guarding good practices in the development of these services and examines the concepts of leadership and outlines the definitions and theories of humor and research about functional humor as related specifically to the leadership arena. Finally, some practical methods are suggested on incorporating humor in leadership practices. 


\section{Administration of Students' Services Deliveries}

A number of academic disciplines informs higher educational administration leadership and services professional theory and practice. It draws from research in psychology, sociology, mental and physical health services, psychology, education research, management theories, sociology, human resources, marketing, and leadership studies. Consequently, the latest thinking, research, and practice of integration of knowledge from a diverse set of areas of underpin the effectiveness of higher educational leadership that focusses on building, integration and deliver effective student-centric services and support students' academic endeavors, enhancing their personal, social, cultural and cognitive development.

\section{Educational Leadership and Management Skills}

The knowledge of students, the use of educational leadership models, activities programming, and human resources must be crafted together to define, support and expand the mission of effective student affairs and support services. The mandatory leadership skills for higher educational leaders minimally include the following:

(a) curriculum development and program design;

(b) budget development and resource allocation;

(c) program administration;

(d) effective operation within the context of institutional governance and governmental policies;

(e) marketing of accomplishments;

(f) research, evaluation, assessment and knowledge of students;

(g) staff supervision and professional development;

(h) strategic planning, mission and vision development;

(i) legal dimensions of working with university/college students; and

(j) integration of appropriate technology into program/service delivery.

Therefore, there is a need for a flexible leadership and management style for effective leadership to deliver in a diversified environment. 


\section{Leadership and Humor Theories and Research}

Leadership, viewed from a functional approach involve strong elements of communication and the practical use of humor presupposes some level of knowledge, definitions and theories of humor. Theories and research about functional humor as related specifically to communication and leadership arena are presented and this article lists some observations and comments on humor in leadership.

\section{Communication in Leadership Theories}

Leadership is a social influence process whereas leader typically refers to a person who occupies a position within a group structure (Fisher, 1985). Brilhart \& Galanes (1989), Tannenbaum, Wechsler, \& Massarik (1988) and Hoy \& Miskel (1991) defined leadership as interpersonal influence exercised in a situation and directed through the communication process toward the attainment of specified goals. Such widely accepted definition suggest that a functional and theoretical perspective is integral for explaining leadership process and describes a functional view of leadership with emphasis on the communicative behaviors performed by leaders. The literature reveals five primary viewpoints on leadership: trait, styles, situational or contingency, power, and functional (Hoy \& Miskel, 1991; Jensen \& Chilberg, 1991; Fashiku, 2016). Most contemporary prevailing theories of leadership adopt a contingency approach (Adler, 1989) or a functional perspective (Jensen \& Chilberg, 1991). An effective leader needs to apply both transformational and transactional leadership approaches (Bass \& Avolio, 1993) depending on the different individuals and tasks being undertaken at various points in time. The practical challenge for the leader is to be able to perceive which elements to manage within the context of each particular situation (e.g. people, task, team, and other contextual information). From a contingency approach, successful leadership requires both personal dimensions and situational variables. That is, the best leadership style is flexible and allow leaders to emphasize a task and manage relationship strategy appropriate to the particular situation. 
A functional view of leadership behaviors is performance-based rather than descriptive of the traits or styles of leaders. Researchers using functional perspective have stated two primary dimensions of leadership behaviors: task and social (Fisher, 1980; Hoy \& Miskel, 1991). Bales (1970) identified specific categories of behaviors grouped into general dimensions of task functions and socioemotional functions. Task functions move groups toward task completion, whereas socioemotional roles are oriented toward the functioning of the group responsible for tasks completion. Other studies have reported distinctions between task and social leaders (Bales \& Slater, 1955; Burke, 1967, 1992), instrumental and expressive needs (Etzioni, 1965), goal achievement and group maintenance objectives, between group task roles and group building and maintenance roles (Holmes \& Marra, 2002), and between initiating structure and consideration functions (Hoy \& Miskel, 1991). Although earlier theorists suggested that mutually exclusive leadership behaviors are necessary for task achievement and for group maintenance, more recent researchers have proposed the two dimensions are interdependent (Wheeless, Wheeless \& Dickson-Markman, 1982). That is, every leadership communication act reflects both a task and a social dimension. Therefore, the functional perspective of leadership communication is concerned with task and social behaviors that help groups function more effectively and efficiently. This functional view has been applied to the use of humor as a form of communication (Graham, Papa \& Brooks, 1992).

Studies on leadership literature have reported the use of humor as an important leadership skill and communication style for effective leadership. Although some suggested that a sense of humor is simply a critical trait of leaders (Robert, Dunne \& Iun, 2015; Fisher \& Robbin, 2014), others have emphasized the functional role of humor (Wijewardena, Hartel \& Samaratunge, 2017) . For example, Crawford, Nerina \& Caltabiano (2011) and Valle, Kacmar, Micki \&Andrews (2018) described humor as one of the behaviors indicative of the harmonizing function of group maintenance. Cann \& Kuiper (2014) identified humor and laughing as representative of the positive socioemotional function of showing psychological and tension release, and improved organizational creativity (Lang \& Lee, 2010). Fisher (1980) and Firestein (1990) proposed that a humorous group member function 
in an informative task and a harmonizing maintenance role. Brilhart \& Galanes (1989) cited the importance of humor as a leadership function that help reduce tensions among group members, and improve positive personality (Cann, Stilwell \& Taku, 2010), Cann \& Matson (2014), and concluded that productive leaders need to see interjecting humor serve an important communication choice for leaders.

\section{Definitions and Theories of Humor}

Humor is defined as a multi-paradigmatic, multi-faceted and systematic process to elicit psychologic, neuropsychologic, social, and cognitive reactions, evolutionary and developmental psychology, to the organizational psychology, and many more (Pluta, 2003). Martineau (1972) described humor more specifically as a distinctive type of medium of communication by which persons convey information during interaction. Humor is complex, multifaceted and manifests as jokes, puns, funny stories, laughter, banter, teasing, satire, sarcasm, ironic remarks, ridicules, humorous behaviors and as a stimulus response, and as disposition (Martin, 2007). Chapman \& Foot (1976) identified humor as a stimulus and any communication specifically intended to provoke laughter or smiling, and as a stimulus from the context of public speaking to convey critical information designed to elicit positive reactions (Watson \& Drew, 2017; Markiewicz, 1974). Scholars have categorized types of humor as stimuli or described conditions under which humor may be experienced (Rybacki \& Rybacki, 1991). As a response, humor has been defined as the amount of laughter or smiling observed in a situation (Galloway, 2010) and humorous laughter as involuntary physical expression of amusement (Morreall, 1987, 1991). Pluta, (2013) posited that laughter is studied in tandem with humor, or elicitation of laughter. Many definitions and theories of humor, intended to explain why a communication is funny, are actually theories of laughter. In summary, a personality inclusive of disposition and use of humor is considered a good leadership trait. 


\section{Theories of Humor}

Humor theories have fallen into one of three broad theoretical perspectives: superiority, incongruity, and relief theories (Foot, 1986; Haig, 1988; Morreall, 1987, 1991). Although no single theory is comprehensive to explain humor alone, some combination of theories may adequately explain all aspects of the phenomenon of humor (Kuhlman, 1985).

Superiority theories contend that all humor originates from the users' feeling of perceived superiority over another or over previous situation. Foot, (1986) and Morreall (1987) derision theory, suggested humor as the derived glorification from grimaces called laughter, caused either by some sudden act of their own that pleases them or by the apprehension of some deformed thing in another. Much of the research that has examined humor from a superiority perspective deals with aggressive, disparaging, and self- deprecating humor, which elevates individuals above the target of the humor (Zillmann, 1983). Incongruity theory perspective address the cognitive processes involved in perceiving humor and reacting to incongruities from two primary directions. The first direction suggests that humor results from the surprising discovery of an incongruity itself while the second considers humor to be a reaction to discovering two seemingly incongruous elements are actually related (Suls, 1983). Leaders should therefore ensure a connection of the joke to the tasks and the incongruities involved in accomplishing the tasks.

The final perspective, relief theory, includes a variety of theories that fall into psychological and physiological domains. A common ingredient among these theories is that laughter is a release of repressed or unused energy. Freud's psychoanalytic theory has been the most prominent of this type (McGhee, 1979). Freud (1961) suggested that laughter is an outlet for psychic or nervous energy, particularly sexual and aggressive inhibitions. Additionally, two types of arousal theories have gained acceptance as theories of humor and laughter (Godkewitsch, 1972; Langevin \& Day, 1972). The first approach is that humor itself raises the state of arousal, which causes pleasure; to balance this arousal, the person laughs. The second approach is that an individual is aroused to such an uncomfortable state by a joke or a situation 
as it develops that the humorous punchline or ending, and therefore the removal of the discomfort, causes pleasure and laughter. As Giles, Bourhis, Gadfield, Davies \& Davies (1976) theorized, failure to perceive or comprehend the humor, and thus failure to relieve the discomfort would elicit frustration. Leaders must therefore draw the fine line between these approaches as they integrate the types and approach of humor into their leadership styles within higher educational administration.

\section{Types of Humor}

\section{Affiliative Humor}

Affiliative humor users joke around with others and attract them with forms of humor that focus on enhancing social interaction. Examples of affiliative humor include funny stories particular to a group, insider jokes, and good-natured practical jokes that are traditionally played on people during social events. Individuals who exhibit this behavior are liked by others and are usually perceived as non-threatening (Vaillant, 1977). By utilizing this style of non-hostile and affirming humor, one lessens interpersonal tensions and aid in relationship building (Martin, Puhlik-Doris, Larsen, Gray \& Weir, 2003). Affiliative humor is like a social lubricant that facilitates interpersonal interaction and creates positive environment. This approach is particularly usable in higher educational leadership roles or professionals that design, implement and oversee diverse programs in higher educational, and interact heavily with students' administration services.

\section{Self-Enhancing Humor}

People who exhibit self-enhancing humor have a humorous view of life and are not overly distressed by its inevitable tribulations. This humor style is a coping mechanism for dealing with stress, which assists in maintaining positive perspective. Self-enhancing humor is negatively related to neuroticism and positively related to self-esteem and favorable emotions. This humor style is centered more on the individual when compared to affiliative humor (Martin et al. 2003) and is very usable in higher educational institution organizational leadership when the initiator's intention is to 
enhance the users' image and experience relative to others in the group or organization.

\section{Aggressive Humor}

Aggressive humor often aims to manipulate others by means of an implied threat of ridicule (Janes \& Olsen 2000). Aggressive humor is used to victimize, belittle, and cause others some type of disparagement (Zillman 1983). This style of humor is consistent with superiority theory, which postulates people make themselves feel better at another's expense to achieve, or perceive that they have achieved higher rank or status (de Koning \& Weiss, 2002). Aggressive humor is negatively related to agreeableness and conscientiousness while positively related to neuroticism (Martin et al. 2003).

\section{Mild Aggressive Humor}

Mild aggressive humor can have positive functions as a trait or application in enhancing leadership style. Studies have postulated that observing other people being ridiculed is related to conforming behaviors, which is constructive in cohesive teams' building (Janes \& Olsen 2000). When manifested as satire or teasing, mild aggressive humor communicates a forceful reprimanding message but with a humorous and positive tone (Meyer 1997, 2000). It also allows expression of disagreement and conflict without the negative affect since the message is delivered in a playful manner (Kahn 1989). This humor type has applications in higher educational leadership traits - especially in working with students that insist in having their ways despite being privy to a fraction of the information for educational leaders and administrators.

\section{Self-Defeating Humor}

Utilizing self-defeating humor ridicule themselves in attempts to amuse and seek acceptance from others (Martin, 2003). A position is that people who use a moderate amount of this humor style often desire to reduce their status level and make themselves more approachable. This is a desirable trait in educational administration leadership where providing services to students is paramount. 


\section{A Functional Perspective of Humor in Communication and Tasks Group}

The section reviews some literature relevant to leadership and use of humor from a functional perspective and examines more closely the functional role of humor in a variety of communicative relationships leaders encounter and in group tasks. Neuendorf and Fennel (1988) confirmed humor as a socially facilitating phenomenon and that laughter is more likely to occur in the presence of others. Others have posited that humor itself, as contrasted with laughter, facilitates a number of communicative functions. Although many have reaped unconditional praises on the use of humor (Debats, 1983; Holmes \& Marra, 2006) and its effectiveness in accentuation of positive leadership styles, others have recommended more caution. Martineau (1972) and Mao, Chiang, Zhang, \& Gao (2017) showed that humor is viewed as both "lubricant" or "abrasive" in social interactions with positive or negative implications for the workplace performance. Another affect-based study concluded that managerial humor, employees' emotions and psychological capital in the workplace and in subordinates (Wijewardena, Hartel \& Samaratunge, 2017). As a lubricant, humor functions to initiate social interaction and keep free and smooth flowing conversations. As an abrasive, humor may cause interpersonal friction that modify the nature of the interaction (Wood, Beckman \& Rossiter, 2011). Humor in managerial communication has been described as both a potentially integrative and a potentially disruptive behavior (Wood, Beckman, \& Rossiter, 2011) and humor is a double-edged tool which may both help and hurt interactions (de Koning \& Weiss, 2002) and provided a framework that includes the presenter, recipient, message, and medium and elaborative cognitive and emotional reactions of the recipients to humor. Because humor is so enigmatic as a form of communication, researchers have attempted to better understand how it functions.

Priest \& Swain (2002), and Mesmer-Magnus, et al (2012) showed positive uses of humor in developing friendships and being playful are positively correlated to communication competence that contributes to a positive workplace, leadership effectiveness, and improve interpersonal skills. For 
example, humor is used to avoid difficult topics or introduce new information (Ullian, 1976). In the right context, humor that attacks or demeans and can signal closeness between people that confirms a safe relationship (Martin \& Lefcourt, 1983, 1984).

Individuals use humor to facilitate self-disclosure (Avant, 1982), to probe one another's values or motives (Linstead, 1985), or to introduce topics that may otherwise be socially inappropriate (Ziv, 1984). Ziv, (1988) and Lippitt (1982) concluded humor also is also used as a coping mechanism for managing anxiety and embarrassment by diverting attention from the situation that caused the embarrassment. Humor can be used to distance unpleasant, stressful, or boring parts of our lives by allowing us to regard them with less seriousness (Linstead, 1985).

As a means of social control, humor function as a control mechanism to express approval or disapproval of actions, especially disapproval of violations of group norms (Webb, 1981). Stephenson (1951) concluded that humor is used to control conflict and behavior, and to reinforce group norms and values by humorously making an example of inappropriate conduct. Collinson (1988) found that joking placed social pressure on workers to conform to cultural norms and motivated workers not meeting work standards. Bradney (1957) determined some humor functioned to control conflicts caused by competition among coworkers and that joking was used to sanction individuals, both formally and informally. Bricker (1980) determined that humor, particularly in the form of joking relationships, was both a mechanism of social control and a tension-reducing device.

The control functions of humor have also been studied from the perspective of social status. Duncan and Feisal (1989) determined that humor helps equalize status among group members, helps assimilate new members into and comfortable of the group the group. Similarly, Huber \& Brown, (2016) and Weaver (2010) showed all are equal in humor. These studies confirm that humor helps define and maintain social groupings and reinforce both social and positional rankings (Boland \& Hoffman, 1982; Duncan, 1982, 1985). 
Robert \& Wilbanks, (2012) and Watson \& Drew (2017) observed that humor tend to be directed downward in a hierarchical organizational structure; that is, higher status persons tended to target lower status colleagues with their humor. Lundberg (1969) noted that lower-ranking group members tend not to joke back with higher status members. Bradney (1957) also found that joking relationships among members of the same status level occur most often, and that when joking occurs between status levels, it is typically aimed downward. Many researchers have reported that humor functions to reduce and manage social distance among individuals and performance management. For example, use of humor helped to facilitate interpersonal attraction and developed friendships (Derks \& Berkowitz, 1989), reduced and managed social distances (Cheatwood, 1983) and improve performance management (Vitug \& Kliener, 2007). Humor also reduced social distance by managing stress and reducing tensions between individuals or among group members (O'Quinn \& Aronoff, 1981). Humor serve the function of gaining approval. If others can be made to laugh, a pleasurable experience, that may dispose them to evaluate the joker's character and viewpoints more favorably (Giles et al 1976). Scogin \& Pollio (1980) determined that humor is used to express appreciative or positive feelings.

In studies conducted in small groups, reduction of social distance typically is expressed in terms of group cohesiveness. Studies that have examined the role of humor in developing cohesion among group members suggested humor enhance morale by decreasing social distance of group members, by forestalling conflict, and provide common ground and as an expression of support or affection, and a way to give new members a sense of belonging (Kaplan \& Boyd, 1965). Linstead (1985) reported humor as a form of symbolic activity that reinforces the social structure and the subculture of a group. Pogrebin \& Poole (1988) presented three functions of humor that operate to build and maintain group cohesiveness. First, it uses allows group members to share common experiences and probe the attitudes, perceptions, and feelings of other group members in nonthreatening manner. Humor helps to translate an individual's concern into a group issue and reinforcing group solidarity. Second, humor promotes social solidarity through the mutual teasing that allows group members realize that they share a common 
perspective. This intra group laughter of inclusion, and humor aimed at people outside the group, helps to define social boundaries. Third, groups utilize humor as a coping strategy in managing a variety of forces beyond their direct control. For example, humor allows group members to laugh at their plight, demonstrating community and reinforcing group cohesion, to show empathy with each other's feelings and allow emotional distancing from a topic by normalizing extraordinary situations (Obrdlik, 1942).

Reference group theory has also influenced humor research. From a reference group perspective, one's membership or lack of it affects reaction toward the use of humor (La Fave \& Mannell, 1976). Martineau (1972) theorized that humor is judged to esteem and solidify groups. However, humor that disparages the group also solidify the group, or it may control behavior of group members, foster conflict in the group, or foster demoralization within the group. Fine (1976) concluded that humor bond group members and form a barrier to outside groups. Linstead (1985) suggested that in defining boundaries, humor directed toward persons outside the group clarify both social and moral boundaries.

From an organizational perspective, humor help socialize new members into the culture of the organization (Vinton, 1989) created bonds among employees and facilitated the accomplishment of work tasks. Also, Vinton (1989) found that self-deprecating jokes informs members that the joke-teller has a sense of humor and willing to participate in the predominant form of humor in the organization: teasing. This teasing functioned in two ways - as task-specific joking that dealt with a work-related task and as social teasing which involved non-work issues. Deal \& Kennedy (1982) proposed that organizational humor bond people together, reduces conflict, create new visions, and regenerate cultural values. Similarly, Lundberg (1969) suggested that humor assist organizational members in earning and maintaining a sense of social inclusion, especially by easing tension and boredom and providing social rewards. Additionally, Lundberg suggested that the amount and type of humor used in an organization indicate the absence or presence of a cohesive social structure. Blau (1963) noted that joking among workers in a competitive situation helped unite the group by allowing them laugh together. 
Nelson (1986), found that humor, in the form of jocular griping, enabled individuals to establish an identity and arrive at consensus and cohesion by creating a group structure with boundaries.

In studies that examined the relationship between humor, leadership, and organizational climate of schools, Ziegler, Boardman \& Thomas (1985) and Hughes \& Avey (2009) showed cheerful, light-hearted humor positively correlated with supportive leadership styles and positive climate. The moderator effect was supported only in relationships between transformational leadership with both trust and affective commitment, suggesting that transformational leaders use more humor rate higher on these outcomes than followers of low humor leaders. Berlyne (1972) suggested that humor is valuable because it attracts attention, provokes thought, helps gain friends, improves communication, helps deal with difficult moments, helps develop positive self-image, motivates and energizes. Smith \& Powell (1988) concluded that self-disparaging humor leaders were perceived as more effective at relieving tension, summarizing group member opinions, and encouraging participation. These leaders were perceived as more willing to share opinions than those who disparaged others. Furthermore, humor is used simply to entertain or gain attention (Boland \& Hoffman, 1982; Bricker 1980). In small groups, Pollio \& Bainum (1983) noted that humor have two effects on group decision making. First, joking and laughing is seen as attempts to reaffirm common bonds and relieve tensions and thereby allowing groups to work more effectively. Second, humor distract groups from its task by calling attention to some specific tension in the group or to the person making the remark but humorous behaviors do not necessarily interfere with a group's task effectiveness. Pollio \& Bainum (1983) demonstrated that if a humorous remark was related to the problem, it served to facilitate task completion but distracted the group, and decreased efficiencies.

Additionally, they determined that task requiring sustained interest and much attention to detail, humorous behaviors did not facilitate effectiveness; but if the task required only shorts, bursts of interest, humorous behaviors, particularly laughter, facilitate performance. Consalvo (1989), in a study of small task-oriented group interactions, showed humor tended to occur in 
patterns associated with particular phases of task-oriented meetings. The initial phase is identified by negative use of humor as adversarial relationships developed. The second phase, a transitional phase, is marked by consensual laughter at humor that appeared to facilitate communication. The laughter then assists the groups in transitioning from a feeling of tension and defensiveness to a realization of relative safety and playfulness. Third, the problem-solving phase is marked by task-oriented efforts and some positive or neutral humor. In some cases, a fourth stage is characterized by clustered humorous episodes about the earlier processes. Consalvo (1989) concluded that humor is an antidote to the stress of the opening phase and facilitated the transition to constructive task effectiveness. Similarly, Scogin \& Pollio (1980) concluded that non-directed humorous remarks provided a group a brief respite needed to keep the group functioning.

Empirical research suggests that humor help groups perform tasks that require creative thought, such as brainstorming projects (Adams, 1986; Von Oech, 1990). Specifically, De Bono (1985) stated "lateral thinking is closely related to insight, creativity, and humor". Ziv (1984) theorized that humor serve to provide a sense of momentary freedom by twisting the usual rules of logical thinking. Von Oech (1990) showed that humor stretches thinking which helps develop alternative ideas, promotes ambiguity and the unusual combinations of ideas, and allows the challenge of conventional rules Albrecht (1980) suggested humor promotes the mental flexibility that leads to innovation and reduce tension in tasks groups promote positive risk-taking behaviors both of which are essential to creativity and creative problem solving (Adams, 1986). Additionally, results in small tasks groups show that deliberate use of humor performed better and more efficiently in problemsolving tasks (Romero, 2008), through enhanced and imaginative stimulation and divergent thinking (Valett, 1981).

This confirms that humor play both positive and negative roles in the communication and leadership process. Leaders must understand the functional nature of humor to effective and appropriate use and for recognizing and responding to inappropriate humor use by subordinates and peers. 


\section{The Practice of Humor in Leadership}

This section reviews use of humor from a practical perspective with emphasis on how leaders can further develop, incorporate sense of humor and promote positive humor within their immediate leadership environments and influence. The literature confirmed an implicit truth that humor performs valuable communicative functions which leaders can use to their advantage to enhance their leadership styles and increase productivity. However, there is no uniform agreement on the benefit of humor in leadership or organizations (Smeltzer \& Leap, 1988) or how humor functions as a leadership character or management behavior (Smith \& Powell, 1988). Studies agree that humor have both a positive and a negative force in groups and is a double-edged leadership tool (Malone, 1980) and an interpersonal assest and liability to managers (Mettee, Hrelec \& Wilkens, 1971). Murdock \& Ganim, (1993) for example advocated for an increased awareness of the good and bad humor in the workplace and for leaders to be attentive to both forms before its use, and that leaders learn what types of humor behaviors to utilize during their interactions with groups and individuals. Due to differences in sense and perception of humor, what is funny to one person or group can spark negative feelings in others (Maples et al. 2001). Negative humor includes humor-based activities that result in repression, humiliation, degradation and intentional or unintentional distress in organizations Unwelcome ethnic and sexist jokes, insults, humiliation, and malicious ridicule are some examples of negative humor (Clouse \& Spurgeon 1995). Additionally, individuals who use too much humor can lose credibility.

In organizations including higher educational institutions, using humor in service encounters is an ingenious affiliative behavior that strengthens rapport between service employees and their (students) customers (Slåtten, Svensson, Sværi, 2011). Humor permits frontline service employees to better cope with the emotional challenges of their work, reduce the emotional labor and increase well-being of service frontline employees. The effectiveness of service recovery efforts also grows when employees use humor successfully to soften unpleasant emotional reactions (Mathies et al, 2016). The use of humor in improvements of services delivery has been proposed to trigger a 
natural physiological response experienced by both the sender and the receiver, and allows for a humanizing effect that creates a connection between two or more parties. When applying comedy concepts to business, the speaker may utilize the three components of comedy or apply improvisation principles. However, the presenter should use comedy that is carefully calibrated and without using offensive material.

\section{Conclusions}

The literature supports the assumption that humor, when used appropriately employed by leaders play an important role in enhancing leadership styles and effectiveness of services deliveries, employees' job related affective well-being. The literature indicates there are relationships between the use of humor and several critical leadership functions, including creativity, interpersonal relations, team-building, enhancement of groups decisions-making skills, boosting creativity, improve interpersonal relations and team-building, leadership effectiveness, and improved organizational leadership, performance management in complex and integrated environments, including those in higher educational administration. Leaders' aggressive humor in interpersonal communication have positive contributions to employees' job related negative affective well $\neg$ being a positive role to making work more enjoyable by undermining power and status that inhibit effective work relationships. Therefore, for organizations, a proactive approach is to involve self-enhancing humor as an important criterion in the selection process of leaders and managers.

Leaders must realize that it is their responsibility to create the humorous environment within their workplace (Duncan 1985; 1989). A practical method include organizational sponsorship and promotion of humor events has been proposed (Robert \& Wilbanks, 2012) and creating a conducive environments where appropriate humor is incorporated into groups activities. Managers should encourage collective and individual use of humor among their subordinates to show acceptance of this mode of communication. Krohe (1987) suggested leadership use of humor more often reduce or eliminate the 
perception and fear of reaction from their superiors. Leaders must therefore create an atmosphere conducive to humor use. Additionally, leaders must set the example of what types of humor are appropriate. This humor role modeling is an important function of leadership in the work place. The handy rule suggested by Goodman (1983) may prove valuable: humor is laughter made from pain -- not pain inflicted by laughter. Leaders must recognize that humor is risky, that one may need to "dare to be foolish" (Metcalf \& Felible, 1992). There are times humor in leadership and places where humor is not appropriate. Bradford (1976) warned that too much clowning and joking create an atmosphere of play that interferes with work. Comic relief can help lighten a meeting, while persistent joke telling can disrupt a discussion. Humor may be acceptable during breaks and certain meetings, but may be less proper during a disciplined conference. Furthermore, a leader need to gauge employee tolerance for humor during meetings; those who are disturbed by the inefficient use of time caused by humor may become frustrated and may contribute less to the task. A balance must be maintained. Additionally, there are types of humor that are rarely appropriate. Prejudicial humor -including sexist or sexual, racist, and ethnic humor, is never appropriate in today's workplace (Krohe, 1987; Smeltzer and Leap, 1988). Leaders must take into account the people who follow and realize inappropriate humor may alienate workers. Such alienation might have a more profound impact on an organization than merely tension between the subordinates and the leader.

Humor and leadership are risky. Leaders should utilize tools that help to be more effective at motivating followers, achieving goals, and developing communication relationships. Humorous relationship is one of the communication choices available to every leader. With some knowledge and common sense about its use, leaders can use humor effectively as part of their repertoire of communication skills.

\section{References}

Adams, J. L. (1986). The care and feeding of ideas: A guide to encouraging creativity. Reading, MA: Addison-Wesley. 
Adler, R. B. (1989). Communicating at work: Principles and practices for business and the professions (3rd Ed.). New York: Random House.

Albrecht, K. (1980). Brainpower: Learn to improve your thinking skills. Englewood Cliffs, NJ: Prentice-Hall.

Alexander, F. K. (2000). The Changing Face of Accountability: Monitoring and Assessing Institutional Performance in Higher Education. The Journal of Higher Education, 71, 411-431.

Amey, M. J. (2006). Leadership in Higher Education. Change: The Magazine of Higher Learning, 38, 55-58.

Astin, A. W., \& Astin, H. S. (2000). Leadership Reconsidered:Engaging Higher Education in Social Change. Battle Creek, MI: W.K. Kellogg Foundation.

Avant, K. M. (1982). Humor and self-disclosure. Psychological Reports, 50, 253-254.

Bales, R. F. (1970). Perspectives and Theory. Small Group Research, 1, 315326.

Bales, R. F., \& Slater, P. E. (1955). Role differentiation in small decisionmaking groups. In T. Parsons \& R. F. Bales (Ed) Family, socialization and interaction process. Glencoe, IL: Free.

Banning, M.S. \& Nelson, D.L. (1987). The Effects of Activity-Elicited Humor and Group Structure on Group Cohesion and Affective Responses. American Journal of Occupational Therapy, 41, 510-514.

Bass, B. M., \& Avolio, B. J. (1993). Transformational leadership and organizational culture. Public Administration Quarterly, 17, 112-121.

Berlyne, D. E. (1972). Humor and its kin. In J. H. Goldstein \& P. E. McGhee (Ed), The psychology of humor: Theoretical perspectives and empirical issues. New York: Academic.

Black, S.A. (2015). Qualities of Effective Leadership in Higher Education, Open Journal of Leadership, 2015, 54-66

Blau, P. M. (1963). The dynamics of bureaucracy: A study of interpersonal relations in two government agencies (rev. Ed.). Chicago: University of Chicago.

Boland, R. J. \& Hoffman, R. (1982). Humor in a machine shop: An interpretation of symbolic action. In P. J. Frost, V. F. Mitchell, \& W. R. Nord (Eds.), Organizational reality: Reports from the firing line (pp. 372-377). Glenview, IL: Scott, Foresman. 
Bradford, L. P. (1976). Making meetings work: A guide for leaders and group members. La Jolla, CA: University Associates.

Bradney, P. (1957). The joking relationship in industry. Human Relations, 10, 179-187.

Bricker, V. R. (1980). The function of humor in Zinacantan. Journal of Anthropological Research, 36, 411-418.

Brilhart, J. K., \& Galanes, G. J. (1989). Effective group discussion (6th Ed.). Dubuque, IA: Wm. C.Brown.

Burke, P. J. (1967). The development of task and social-emotional role differentiation. Sociometry, 30, 379-392.

Burke W. \& Litwin G. (1992). A Causal Model of Organizational Performance \& Change, Journal of Management, 18, 523 - 545.

Cann, A., \& Matson, C. (2014). Sense of humor and social desirability: Understanding how humor styles are perceived. Personality and Individual Differences, 66, 176-180.

Cann, A., Stilwell, K., \& Taku, K. (2010). Humor styles, positive personality, and health. Europe's Journal of Psychology, 6, 213-235.

Cann, A., \& Kuiper, N.A. (2014). Sense of humor and social desirability: Understanding how humor styles are perceived. Europe's Journal of Psychology, 10, 412-428.

Cartwright, D., \& Zander, A. (Eds.). (1968). Group dynamics: Research and theory (3rd Ed.). New York: Harper \& Row.

Chapman, A. J., \& Foot, H. C. (1976). Introduction. In A. J. Chapman \& H.

C. Foot (Eds.), Humour and laughter: Theory, research, and applications (pp. 1-7). New York: John Wiley and Sons.

Chapman, A. J., \& Gadfield, N. J. (1976). Is sexual humor sexist? Journal of Communication, 26, 141- 153.

Cheatwood, D. (1983). Sociability and the sociology of humor. Sociology and Social Research, 67, 324- 338.

Chiew, T.M., Mathies, C. \& Patterson, P. (2019). The effect of humour usage on customer's service experiences. Australian Journal of Management, 44, 109-127.

Clouse, R.W.\& Spurgeon, K.L. (1995). Corporate analysis of humor. Psychology: A Quarterly Journal of Human Behavior, 32, 1-24.

Collinson, D. L. (1988). Engineering humour: Masculinity, joking and conflict in shop-floor relations. Organization Studies, 9, 181-199. 
Consalvo, C. M. (1989). Humor in management: No laughing matter. International Journal of Humor Research, 2, 285-297.

Cooper, C.D. (2005), Just joking around? Employee humor expression as an ingratiatory Behavior. Academy of Management Review, 30, 765-76.

Crawford, S.A., Nerina J. \& Caltabiano, N.J. (2011) Promoting emotional well-being through the use of humour. The Journal of Positive Psychology, 6, 237-252

Davies, J., Hides, M. T., \& Casey, S. (2001). Leadership in Higher Education. Total Quality Management, 12, 1025-1030.

de Bono, E. (1985). Six thinking hats. New York: Viking Penguin.

de Koning, E. D. \& Weiss, R. L. 2002. The relational humor inventory: Functions of humor in close relationships. The American Journal of Family Therapy, 30, 1-18.

Deal, T. E., \& Kennedy, A. A. (1982). Corporate cultures: The rites and rituals of corporate life. Reading, MA: Addison-Wesley.

Debats, K. E. (1983). Humor relations for fun and profit. Personnel Journal, 61, 346-348.

Derks, P., \& Berkowitz, J. (1989). Some determinants of attitudes toward a joker. International Journal of Humor Research, 2, 385-396.

Drew, G., Ehrich, L. C., \& Hansford, B. C. (2008). An exploration of university leaders' perceptions of leadership and learning. Leading \& Managing, 14, 1-18.

Duncan, W. J. (1985). The superiority theory of humor at work: Joking relationship as indicators of formal and informal status patterns in small, task-oriented groups. Small Group Behavior, 16, 556-564.

Duncan, W. J., \& Feisal, J. P. (1989). No laughing matter: Patterns of humor in the workplace. Organizational Dynamics, 17, 18-30.

Etzioni, A. (1965). Dual leadership in complex organizations. American Sociological Review, 30, 688- 698.

Fashiku, C. O. (2016). Leaders' communication pattern: a predictor of lecturers job performance in Nigeria. International Journal of Educational Leadership and Management, 4, 103-126

Fine, G. A. (1976). Obscene joking across cultures. Journal of Communication, 26, 134-140. 
Firestien, R.L. (1990). Effects of Creative Problem Solving Training on Communication Behaviors in Small Groups. Small Group Research, $21,507-521$.

Fisher, B. A. (1980). Small group decision making: Communication and the group process (2nd Ed.). New York: McGraw-Hill.

Fisher, B. A. (1985). Leadership as medium: Treating complexity in group communication research. Small Group Behavior, 16, 167-196.

Fisher, F. \& Robbins, C.R. (2014). Embodied leadership: Moving from leader competencies to leaderful practices. Leadership, 11, 281-299.

Foot, H. (1986). Humour and laughter. In 0. Hargie (Ed.), A handbook of communication skills (pp. 355- 382). Washington Square, NY: New York University.

Freud, S. (1961). The ego and the id. In J. Strachey (Ed. and Trans.), The standard edition of the complete psychological works of Sigmund Freud (Vol. 19, pp. 3-66). London: Hogarth Press

Galloway, G. (2010). Individual differences in personal humor styles: Identification of prominent patterns and their associates. Personality and Individual Differences, 48, 563-567.

Giles, H., Bourhis, R. Y., Gadfield, N. J., Davies, G. J., \& Davies, A. P. (1976). Cognitive aspects of humour in social interaction: A model and some linguistic data. In A. J. Chapman \& H. C. Foot (Eds.), Humour and laughter: Theory, research, and applications (pp. 139-154). New York: John Wiley and Sons.

Gigliotti, R. A. (2017). Academic leadership education within the Association of American Universities. Journal of Applied Research in Higher Education, 9, 196-210.

Gigliotti, R. A. \& Ruben, B. D. (2017). Preparing higher education leaders: A conceptual, strategic, and operational approach. Journal of Leadership Education, 16, 96-114.

Gmelch, W. H. \& Buller, J. L. (2015). Building academic leadership capacity: A guide to best practices. San Francisco: Jossey-Bass.

Godkewitsch, M. (1972). The relationship between arousal potential and funniness of jokes. In J. H. Goldstein \& P. E. McGhee (Eds.), The psychology of humor: Theoretical perspectives and empirical issues (pp. 143-158). New York: Academic. 
Goodman, J. (1983). How to get more smileage out of your life: Making sense of humor, then serving it. In P. E. McGhee \& J. H. Goldstein (Eds.), Handbook of humor research: Volume II. Applied studies. New York: Springer-Verlag.

Graham, E. E., Papa, M. J., \& Brooks, G. P. (1992). Functions of humor in conversation: conceptualization and measurement. Western Journal of Communication, 56, 161-183.

Haig, R. A. (1988). The anatomy of humor: Biopsychosocial and therapeutic perspectives. Springfield, IL: Charles C Thomas.

Holmes, J. \& Marra, M. (2002). Having a laugh at work: How humour contributes to workplace culture. Journal of Pragmatics, 34, 16831710.

Holmes, J. \& Marra, M. (2006). Humor and leadership styles. International Journal of Humor Research, 19,119-138

Hoy, W. K., \& Miskel, C. G. (1991). Educational administration: Theory, research, practice (4th Ed.). New York: McGraw-Hill.

Huber, G. \& Brown, A.D. (2016). Identity Work, Humour and Disciplinary Power. Organization Studies, 38, 1107-1126.

Hughes, L.W. \& Avey, J. B. (2009). Transforming with levity: humor, leadership, and follower attitudes, Leadership \& Organization Development Journal, 30, 540-562.

Janes, L. M. \& Olsen, J. M. 2000. Jeer pressure: The behavioral effects of observing ridicule of others. Personality and Social Psychology Bulletin, 26, 474-485.

Jensen, A. D., \& Chilberg, J. C. (1991). Small group communication: Theory and application. Belmont, CA: Wadsworth.

Kahn, W. 1989. Toward a sense of organizational humor: Implications for organizational diagnosis and change. The Journal of Applied Behavioral Science, 25, 45-63.

Kaplan, H. B., \& Boyd, I. H. (1965). The social functions of humor on an open psychiatric ward. Psychiatric Quarterly, 39, 502-515.

Kieu, H. Q. (2010). Leadership Styles and Organizational Performance: A Predictive Analysis: ERIC retrieved from https://eric.ed.gov/?id=ED525809

Krohe, J., Jr. (1987). Take my boss -- please. Across the Board, 24, 31-35. 
Kuhlman, T. L. (1985). A study of salience and motivational theories of humor. Journal of Personality and Social Psychology, 49, 281-286.

La Fave, L., \& Mannell, R. (1976). Does ethnic humor serve prejudice? Journal of Communication, 26, 1 16-123.

La Fave, L., Haddad, J., \& Maesen, W. A. (1976). Superiority, enhanced selfesteem, and perceived incongruity humour theory. In A. J. Chapman \& H. C. Foot (Eds.), Humour and laughter: Theory, research, and applications (pp. 63-92). New York: John Wiley and Sons.

Langevin, R., \& Day, H. I. (1972). Physiological correlates of humor. In J. H. Goldstein \& P. E. McGhee (Eds.), The psychology of humor: Theoretical perspectives and empirical issues (pp.129-142). New York: Academic.

Lang, J.C, \& Lee, C. H. (2010). Workplace humor and organizational creativity. The International Journal of Human Resource Management, 21, 46-60

Lemer, H. (2003) The practical qualities for effective leaders. The Scrivener $12,16$.

Linstead, S. (1985). Jokers wild: The importance of humour in the maintenance of organizational culture. Sociological Review, 33, 741767.

Lippitt, G. L. (1982). Humor: A laugh a day keeps incongruities at bay. Training and Development Journal, 36, 98- 100.

Lundberg, C. C. (1969). Person-focused joking: Pattern and function. Human Organization, 28, 22-28.

Malone, P. B. (1980). Humor: A double-edged tool for today's managers? Academy of Management Review, 5, 357-360.

Madanchian, M. Hussein, N., Noordin, F. \& Takerdoost, H. (2016). Economics and Education, 115-119. Retrieved from https://www.researchgate.net/publication/305323612_Effects_of_Lea dership_on_Organizational_Performance

Mak, N.C., Liu, Y. \& Deneen, C.S. (2012). Humor in the workplace: A regulating and coping mechanism in socialization. Discourse \& Communication, 6, 163-179. Retrieved from https://doi.org/10.1177/1750481312437445

Mao, J., Chiang, T., Zhang, Y \& Gao, M. (2017). Humor as a Relationship Lubricant: The Implications of Leader Humor on Transformational 
Leadership Perceptions and Team Performance. Journal of Leadership \& Organizational Studies, 24, 494-506.

Maples, M. F., Dupey, P., Torres-Rivera, E., Phan, L. T., Vereen, L., \& Garrett, M. T. 2001. Ethnic diversity and the use of humor in counseling: Appropriate or inappropriate? Journal of Counseling \& Development, 79, 53-61.

Martin, R. A. (2007). The psychology of humor: an integrative approach. Burlington: Elsevier Academic Press.

Martin, R. A., \& Lefcourt, H. M. (1983). Sense of humor as a moderator of the relation between stressors and moods. Journal of Personality and Social Psychology, 45, 1313-1324.

Martin, R. A., \& Lefcourt, H. M. (1984). Situational Humor Response Questionnaire: Quantitative measure of sense of humor. Journal of Personality and Social Psychology, 47, 145-155.

Martin, R.A., Puhlik-Doris, P., Larsen, G., Gray, J., \& Weir, K. (2003) Individual differences in uses of humor and their relation to psychological well-being: Development of the Humor Styles Questionnaire. Journal of Research in Personality, 37, 48-75.

Mathies, C., Chiew, T.M., Kleinaltenkamp, M. (2016). The antecedents and consequences of humour for service: A review and directions for research, Journal of Service Theory and Practice, 26, 137-162,

Markiewicz, D. (1974). Effects of humor on persuasion. Sociometry, 37, 407422.

Martineau, W. H. (1972). A model of the social functions of humor. In J. H. Goldstein \& P. E. McGhee (Eds.), The psychology of humor: Theoretical perspectives and empirical issues. New York: Academic. McGhee, P. E. (1979). Humor, its origin and development. San Francisco: W. H. Freeman.

McKenzie, E. C. (1980). 14,000 quips and quotes for writers and speakers. New York: Greenwich House.

Mesmer-Magnus, J., Glew, D. J., \& Viswesvaran, C. (2012). A meta-analysis of positive humor in the workplace. Journal of Managerial Psychology, 27, 155-190.

Metcalf, C. W., \& Felible, R. (1992). Lighten up: Survival skills. For people under pressure. Reading, MA: Addison-Wesley. 
Mettee, D. R., Hrelec, E. S., \& Wilkens, P. C. (1971). Humor as an interpersonal asset and liability. Journal of Social Psychology, 85, 51 $-64$.

Meyer, J. C. 1997. Humor in member narratives: Uniting and dividing at work. Western Journal of Communication, 61, 188-208.

Meyer, J. C. (2000). Humor as a double-edged sword: Four functions of humor in communication. Communication Theory, 10, 310-331.

Miller, P. (2019). Leadership communication: the three levels. Retrieved from https://www.researchgate.net/publication/254664129_Leadership_co mmunication_the_three_levels/citation/download

Morreall, J. (1991). Humor and work. International Journal of Humor Research, 4, 359-374.

Morreall, J. (Ed.). (1987). The philosophy of laughter and humor. Albany, NY: State University of New York.

Murdock, M. C. \& Ganim, R. M. 1993. Creativity and humor: Integration and incongruity. Journal of Creative Behavior, 27,57-70.

Napier, R. W., \& Gershenfeld, M. K. (1989). Groups: Theory and experience (4th Ed.). Boston: Houghton Mifllin.Nelson, R. B. (1985). Louder and funnier: A practical guide for overcoming stage/right in speechmaking. Berkeley, CA: Ten Speed.

Neuendorf, K. A., \& Fennel, T. (1988). A social facilitation view of the generation of humor and mirth reactions: Effects of a laugh track. Central States Speech Journal, 39, 37-48.

Nolan, M. (1986). Success can be a laughing matter. Data Management, 24, 28-29.

O'Quin, K., \& Aronoff, J. (1981). Humor as a technique of social influence. Social Psychology Quarterly, 44, 349-357.

Obrdlik, A. J. (1942). "Gallows humor" -- a sociological phenomenon. American Journal of Sociology, 47, 709-716.

Pluta, P. (2013). What is humor? An attempt at definition. (2013). Psychology ofHumor. Retrieved from http://www.psychologyofhumor.com/2013/09/01/what-is-humor-anattempt-at-definition/

Pogrebin, M. R., \& Poole, E. D. (1988). Humor in the briefing room: A study of the strategic uses of humor among police. Journal of Contemporary Ethnography, 17, 183-210. 
Pollio, H. R., \& Bainum, C. K. (1983). Are funny groups good at solving problems? A methodological evaluation and some preliminary results. Small Group Behavior, 14, 379-404.

Priest, R.F, \& Swain, J.E. (2002). Humor and its implication for leadership effectiveness. Humor, 15, 169-189

Riesh, H. Why did the proton cross the road? Humour and science communication. Public Understanding of Science, 24, 768-775

Ruben, B. D. \& Gigliotti, R. A. (2017). Communication: Sine qua non of organizational leadership theory and practice. International Journal of Business Communication, 54, 12-30.

Robert, C., Dunne \& Iun (2015). The Impact of Leader Humor on Subordinate Job Satisfaction: The Crucial Role of Leader-Subordinate Relationship Quality. Group \& Organization Management, vol. 41, 375-406.

Robert, C. \& Wilbanks, J.E. (2012). The wheel model of humor: Humor events and affect in organizations. Human Relations, 65, 1071-1099.

Romero, E., \& Pescosolido, A. (2008). Humor and group effectiveness. Human Relations, 61,

Rybacki, K., \& Rybacki, D. (1991). Communication criticism: Approaches and genres. Belmont, CA: Wadsworth.

Scogin, F. R., Jr., \& Pollio, H. R. (1980). Targeting and the humorous episode in group process. Human Relations, 33, 831-852.

Slåtten, T., Svensson, G., Sværi, S. (2011). Empowering leadership and the influence of a humorous work climate on service employees' creativity and innovative behavior in frontline service jobs, International Journal of Quality and Service Sciences, 3, 267-284,

Smeltzer, L. R., \& Leap, T. L. (1988). An analysis of individual reactions to potentially offensive jokes in work settings. Human Relations, 41, 295304.

Smith, C. M., \& Powell, L. (1988). The use of disparaging humor by group leaders. Southern Speech Communication Journal, 53, 279-292.

Stephenson, R. M. (1951). Conflict and control functions of humor. American Journal of Sociology, 56. 569-574.

Suls, J. M. (1983). Cognitive processes in humor appreciation. In P. E. McGhee \& J. H. Goldstein (Eds.), Handbook of humor research: Volume /. Basic Issues (pp. 39-58). New York: Springer-Verlag. 
Tannenbaum, R., Wechsler, 1. R., \& Massarik, F. (1988). Leadership: A frame of reference. ln R. S. Cathcart \& L. A. Samovar (Eds.), Small group communication: A reader (5th ed., pp. 483-492). Dubuque, IA: Wm. C. Brown.

Ullian, J. A. (1976). Joking at work. Journal of Communication, 26, 129-133. Vaillant, G. E. 1977. Adaptation to life. Toronto: Little, Brown, \& Co.

Valett, R. E. (1981). Developing the sense of humor and divergent thinking. Academic Therapy, 17, 35- 42.

Valle, M., Kacmar, Micki M. \&Andrews, M. (2018). Ethical leadership, frustration, and humor: a moderated-mediation model. Leadership \& Organization Development Journal, 39, 665-678.

VanGundy, A. B. (1984). Managing group creativity: A modular approach to problem solving. New York: American Management Associations.

Vitug, M., Kleiner, B. (2007). How can comedy be used in business? International Journal of Productivity and Performance Management, 56, 155-161,

Vinton, K. L. (1989). Humor in the workplace: It is more than telling jokes. Small Group Behavior, 20,151-166.

Von Oech, R. (1990). A whack on the side of the head: How you can be more creative (rev. Ed.). New York: Warner.

Warren, C., \& McGraw, A. P. (2016). Differentiating what is humorous from what is not. Journal of Personality and Social Psychology, 110, 407430.

Watson, C. \& Drew, V. (2017). Humour and laughter in meetings: Influence, decision-making and the emergence of leadership. Discourse \& Communication, 11, 314-329.

Weaver, S (2010) The 'other' laughs back: Humour and resistance in antiracist comedy. Sociology, 44, 31-48.

Webb, R. G. (1981). Political uses of humor. Et cetera, 38, 35-50.

Wheeless, L. R., Wheeless, V. E., \& Dickson-Markman, F. (1982). A research note: The relations among social and task perceptions in small groups. Small Group Behavior, 13, 373-384.

Wijewardena, N., Hartel, C. \& Samaratunge, R. (2017). Using humor and boosting emotions: An affect-based study of managerial humor, employees' emotions and psychological capital. Human Relations, 70, 1316-1341. 
Wood, R.E., Beckman, N. \& Rossiter, J.R. (2011). Management humor: Asset or liability? Organizational Psychology Review, 1, 316-338.

Ziegler, V., Boardman, G., \& Thomas, M. D. (1985). Humor, leadership, and school climate. Clearing House, 58, 346-348.

Zillmann, D., \& Stocking, S. H. (1976). Putdown humor. Journal of Communication, 26, 154-163.

Ziv, A. (1984). Personality and sense of humor. New York: Springer.

$\mathrm{Ziv}$, A. (1988). Humor's role in married life. International Journal of Humor Research, 1, 223-229.

Beverlyn E. Grace-Odeleye Assistant Professor and Director, STAR Program and Summer Bridge Program at East Stroudsburg University of Pennsylvania, East Stroudsburg, Pennsylvania. She has planned and directed academic enrichment and learning programs in universities since 1985 designing programmatic approaches, academic and social contents of educational support program, outcome measurements, and teaching students' support success courses. Additionally, Dr. Grace-Odeleye is a peer-reviewer for submitted proposals, presented and chaired sessions for various national and local conferences on support programs for students' success, retention, persistence, and educational programs administration. Contact Address: Department of Academic Enrichment \& Learning, Rosenkrans East, East Stroudsburg University of Pennsylvania, East Stroudsburg, PA 18301-2999. E-mail: beverlyn@esu.edu

Jessica Santiago, Ph.D. is an academic coach on the Summer Bridge Program at East Stroudsburg University of Pennsylvania, East Stroudsburg, Pennsylvania. She supports the planning and implementation of the Summer Bridge team and manages the unit's data collection. Additionally, she is a trainer for Summer Bridge peer mentors, tracks students' performances and provide academic coaching and counseling year-round at the Department of Academic Enrichment and Learning.

Contact Address: East Stroudsburg University, Department of Academic Enrichment \& Learning, East Stroudsburg University of Pennsylvania, East S Stroudsburg, PA 18301-2999. E-mail: jsantiago1@esu.edu 